\title{
Assessment of 10-Year Major Osteoporotic and Femur Fracture Risk of Postmenopausal Women Using FRAX ${ }^{\circledR}$ Postmenopozal Kadınlarda FRAX ${ }^{\circledast}$ Skoru Kullanılarak On Yıllık Majör Osteoporotik ve Kalça Kırık Riskinin Değerlendirilmesi
}

\author{
Ayşe DEMiR, Ruhuşen KUTLU, Selma çivi \\ Department of Family Physician, Necmettin Erbakan University Meram Faculty of Medicine, Konya, Turkey
}

\begin{abstract}
Objective: The aim of this study is to assess osteoporosis (OP) risk factors in postmenopausal women and 10-year major osteoporosis and femur facture risks using the World Health Organization's fracture risk assessment scale (FRAX $\left.{ }^{\circledR}\right)$.

Material and Methods: This cross-sectional analytic study was carried out on 340 postmenopausal women. Considering participant risk factors and bone mineral densities and using the FRAX ${ }^{\circledR}$ risk assessment scale, their 10-year major osteoporotic and femur fracture was assessed.

Results: The mean age of the women in our study was $57.5 \pm 7.8$. Of the participants, $47(13.8 \%)$ were osteoporotic, 177 (52.1\%) were osteopenic, and 116 (34.1\%) were normal. As age increased, OP frequency increased $(p<0.001)$, and as body mass index (BMI) increased, OP frequency decreased $(p<0.001)$. Considering OP existence, there was a statistically significant relation between major OP risk and femur fracture risk, calculated using BMD and without using BMD $(\mathrm{p}<0.001)$. Major OP fracture risk, calculated using BMD, was low in $94.7 \%$ of the subjects, mild in $5.0 \%$, and high in $0.3 \%$. When osteoporosis risk factors were assessed, while OP frequency in those with 2 or fewer clinical risk factors (CRFs) was $12.8 \%$, OP frequency was $28.0 \%$ in those with 3 or 4 risk factors.

Conclusion: In this study, it was determined that the FRAX ${ }^{\circledR}$ risk assessment scale, which is used to assess 10-year OP fracture risk, is a significant, cost-efficient, easy-to-use assessment criterion whether BDM is applied or not.
\end{abstract}

Key Words: Osteoporosis, postmenopausal woman, clinical risk factors, FRAX $^{\circledR}$
Özet

Amaç: Bu çalışmanın amacı, postmenopozal kadınlarda osteoporoz (OP) risk faktörlerini ve Dünya Sağlık Örgütü (DSÖ) kırık risk değerlendirme skalası (FRAX) kullanılarak 10 yıllık majör OP ile kalça kırığı riskini değerlendirmektir.

Gereç ve Yöntemler: Kesitsel tipteki bu analitik araştırma 340 postmenopozal kadında yapıldı. Katılımcıların risk faktörleri ile kemik mineral yoğunluklarını (KMY) göz önünde bulundurarak ve FRAX risk değerlendirme skalası kullanılarak 10 yıllık majör osteoporotik ve kalça kırığı riskleri hesaplandı.

Bulgular: Çalışmamızda kadınların yaş ortalamaları 57,5 $\pm 7,8$ idi. Katılanların 47'si $(\% 13,8)$ osteoporotik, 177'si $(\% 52,1)$ osteopenik, 116'sı $(\% 34,1)$ normal olarak bulundu. Yaş arttıkça OP sıklığı artarken $(p<0,001)$, beden kitle indeksi (BKi) arttıkça OP sıklığı azalıyordu $(p<0,001)$. Osteoporoz varlığı göz önüne alındığında, KMY kullanılarak veya kullanılmadan hesaplanan majör osteoporotik ve kalça kırığı riskleri arasında istatistiksel olarak anlamlı derecede önemli bir ilişki vardı $(p<0,001)$. Kemik mineral yoğunlukları kullanılarak hesaplanan majör osteoporotik kırık riski katılanların \%94,7'sinde düşük, \%5'inde orta ve \%0,3'ünde yüksek idi. Osteoporoz risk faktörleri incelendiğinde; 2 ve daha az klinik risk faktörü olanlarda OP sıklığı \%12,8 iken, 3 veya 4 risk faktörü olanlarda bu sıklık $\% 28,0$ idi.

Sonuç: Bu çalışmada, 10 yıllık osteoporotik kırık riskini değerlendirmede KMY kullanılsın ya da kullanılmasın FRAX risk değerlendirme skalasının önemli, maliyet etkin ve kullanması kolay bir değerlendirme kriteri olduğu sonucuna varılmıştır.

Anahtar Kelimeler: Osteoporoz, postmenopozal kadın, klinik risk faktörleri, FRAX ${ }^{\circledR}$ 


\section{Introduction}

Osteoporosis (OP) is characterized with a decrease in bone density and increasing bone fragility, spoiling the micro-structure of bone structure, and affects millions of women and men and is a frequently seen, chronic, progressive, and systemic disease (1-3). Osteoporosis is a serious health problem in our country, as in many other countries (1). In the diagnosis and followup of osteoporosis, double-energy X-ray absorptiometry (DXA) management is used as the golden standard $(4,5)$.

In the Kanis et al. (6) study, major osteoporotic fracture risk ranged between 3.5\%-31.0\% in women; it ranged between $2.8 \%$ and $15.0 \%$ in men aged 50 and over. The treatment threshold for 10-year major osteoporotic fracture risk for 50-yearolds was 7.5\%.

MEDOS is a study on femur fracture that was carried out in 6 European countries, including Turkey. According to the results of this study, femur fracture prevalence linked to osteoporosis in Turkey was determined to be 1.6 in 10,000 and 13 times less compared to European countries, and Turkey was reported to be a low-risk area according to the MEDOS study $(7,8)$. A parental history of fracture (particularly a family history of hip fracture) means an increased risk of fracture.

In this study, our aim is to assess postmenopausal (PM) women who applied with any reason to the Family Practice Polyclinic in terms of osteoporosis risk factors and to calculate 10-year major osteoporotic and femur fracture risks with FRAX scores by measuring bone mineral density with DXA.

\section{Material and Methods}

\section{Study Design, Setting, and Population}

This cross-sectional analytical study was carried out on 340 postmenopausal women who applied with any reason to the Family Practice Polyclinic of Necmettin Erbakan University between March 2010 and February 2011. Before starting the study, it was endorsed by the ethical board (Number:2010/053) of Meram Medical Faculty of Medicine. The number of women to be included into the study was found to be 328 , according to the $30 \%$ osteoporosis prevalence value, which is determined based on the IPPOT study conducted in our country (9). The participants were informed about the study, and written and oral approvals were obtained from volunteers.

\section{Bone Mineral Density (BMD)}

Bone mineral density (BMD) is a medical term normally referring to the amount of mineral matter per square centimeter of bones. The measurement is painless and non-invasive and involves low radiation exposure. BMD measurement was done with the (DXA) method by using a Lunar GE device (MDL DPX Prodigy-tech. 150070, Madison, USA) in the region of spine (L1L3 ve L2-L4) and proximal femur. Bone densitometry is essential for confirming a diagnosis of osteoporosis and determining the degree of osteopenia $(5,10)$.

According to the osteoporosis definition by the World Health Organization (WHO), if BMD T score is >-1, the person is normal (low risk); if T score is between -1 and -2.5 , osteopenia (more than average risk); if $\mathrm{T}$ score is $<-2.5$, osteoporosis risk is high (high risk); and if T score is <-2.5 and there is existence of fracture, there is established osteoporosis (very high risk) (10).

\section{Fracture Risk Assessment Tool}

In 2008, Kanis et al. (6) carried out a study to determine 10-year fracture risk. With this study, which is entitled A Fracture Risk Assessment Tool (FRAX ${ }^{\mathrm{TM}}$ ), considering femur neck T score and clinical risk factors (CRFs), it is possible to calculate femur fracture and any major osteoporotic fracture for 10 years. Using FRAX scoring, 10-year fracture risk can be automatically calculated. Ten-year fracture risk possibility increases as risk factors increase (11).

The "WHO Fracture Risk Assessment Tool" algorithm, which is known as FRAX ${ }^{\mathrm{TM}}$ and which is accepted by WHO in osteoporotic fracture risk calculation, is entered in the system according to some countries $(12,13)$. According to records, considering that femur fracture incidence has increased since 1988-1989, the FRAX model is to be revised according to the latest data. In this context, based on the results of the FRACTURK study by Tuzun et al. (8), the Turkish model of FRAX was revised in June 2011. In this study, we calculated 10-year fracture risk using $\mathrm{FRAX}^{\circledR}$, which is unique to Turkey (Figure 1) and which was revised in June 2011. In this study, we used the 10-year probability of fracture with BMD and without BMD calculated by using FRAX $^{\circledR}$. Following the assessment of fracture risk using FRAX ${ }^{\circledR}$ in the absence of BMD, the patient may be classified to be at low, intermediate, or high risk.

Threshold Values for Femur and Major Osteoporotic Fracture

Lorenc et al. (14), in their study on osteoporosis method, accepted 2 threshold treatment values for femur and major osteoporotic fracture. The threshold value was between $10.0 \%$ $20.0 \%$ for major osteoporotic fracture and $5.0 \%$ and $10.0 \%$ for femur fracture. If it is $<10.0 \%$ for major osteoporosis, it means low risk; between 10.0 and $20.0 \%$ means mild risk; and if $>20.0 \%$, there is high risk. For femur fracture, $<5.0 \%$ is low risk, mild risk if between 5.0 and $10.0 \%$, and if $>10.0 \%$, there is high risk.

\section{Statistical Analysis}

The encoding and statistical analyses of the data were performed on the computer using the SPSS 13.0 package software. The minimum, maximum, mean, standard deviation, median, and percentages were calculated in the analysis of the data. We used the Pearson correlation coefficient and chi-square test to assess the statistical significance between groups. Linear regression analysis and adjusted $\mathrm{R}$ square were used to compare parameters. The relationship between categorical variables was assessed by using the nonparametric counterparts to the student t-test. A p-value of $<0.05$ was taken as the level of statistical significance.

\section{Results}

Three hundred forty postmenopausal women participated in our study. Mean age of the participants was found to be $57.5 \pm 7.8(\min =44, \max =83$, median $=56)$. While $313(92.1 \%)$ of 


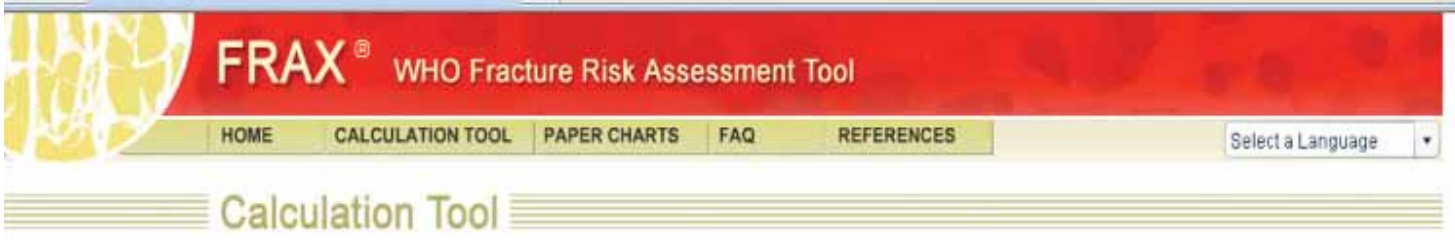

Please answer the questions below to calculate the ten year probability of fracture with BMD.

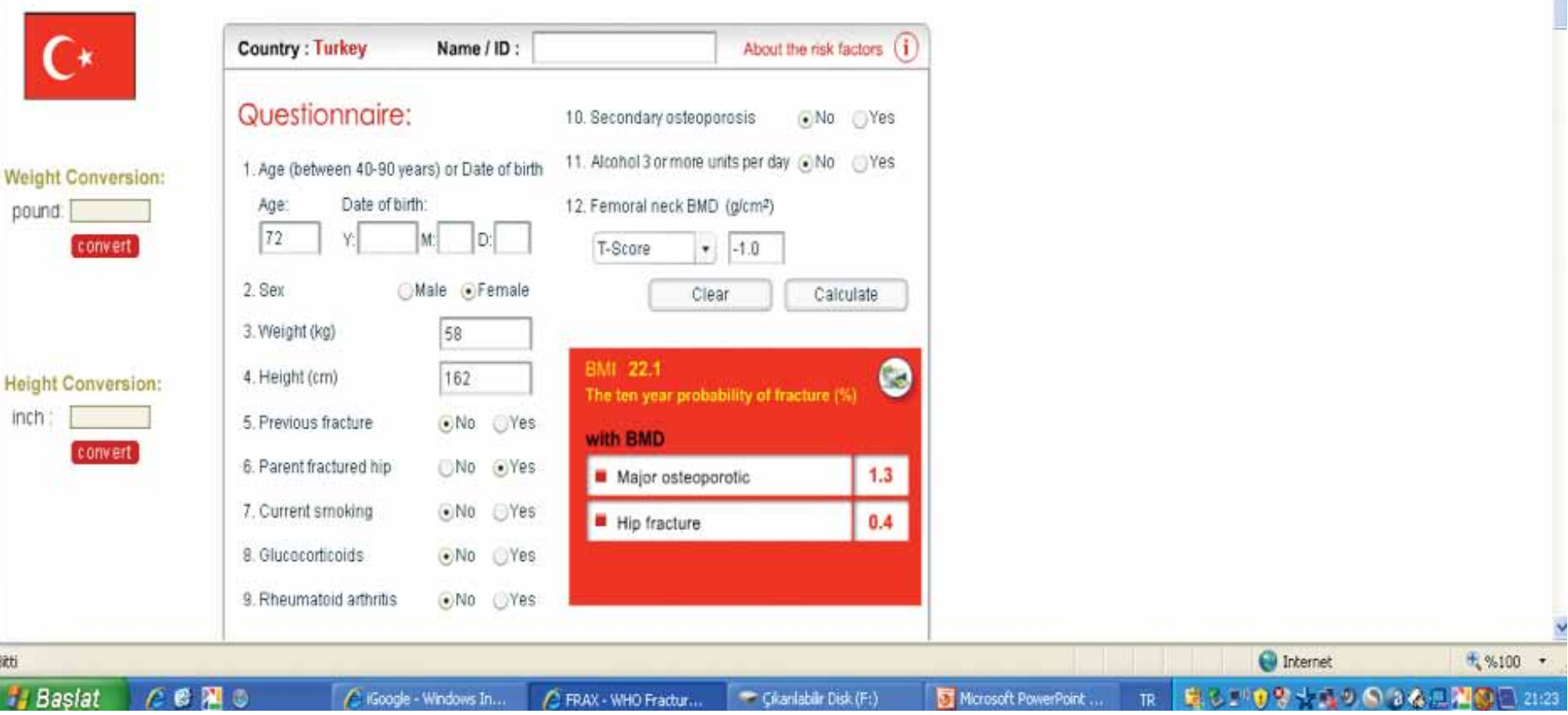

Figure 1. World Health Organization's fracture risk assessment scale (FRAX $\left.{ }^{\circledR}\right)$

participants had 2 or fewer clinical risk factors (CRFs), $25(7.4 \%)$ of them had between 3 and 4 , and 2 of them had (0.6\%) 5 and more CRFs. When femur neck, L1-L4, and femur trochanter DXA results are considered as a whole, 47 (13.8\%) cases were osteoporotic, 177 (52.1\%) of them were osteopenic, and 116 (34.1\%) were found to be normal. The sociodemographic characteristics of participants are shown in Table 1. At 56, which is the median age, and above, OP frequency (20.7\%) was found to be 4.310 times (5.8\%) more compared to those $<56$ year old $[\mathrm{OR}=4.310,95 \% \mathrm{Cl} ;(2.012-9.232)]$, and this difference was statistically significant $\left(\chi^{2}=30.974\right)(p<0.001)$. It was found that as BMl increased, OP frequency decreased $\left(\chi^{2}=20.676\right)(p<0.001)$. No significant relation was found between the number of CRFs; smoking, alcohol, and caffeine consumption; and OP frequency $(p>0.05)$.

Of the participants, $56(16.5 \%)$ had a family history of OP and $23(6.8 \%)$ had a history of fracture at any area of their body in any period in their life from falling, 41 had (12.1\%) a close family member with osteoporotic fracture history, and 13 (3.8\%) had close family members with femur fracture history.
No significant relation was found between OP history in family, fracture and femur fracture history in themselves, and close family and OP frequency ( $p>0.05)$. There was no significant relation between Type 2 DM, hypertension, chronic hepatic disease, malabsorption, RA, hyperthyroid, and hypothyroid existence and OP frequency ( $p>0.05)$.

There was no significant relation between glucocorticoid, heparin, thyroid hormone, anti-convulsion drug, anti-acid drug, and insulin use and hormone replacement treatment (HRT) and OP incidence frequency ( $p>0.05$ ).

When major OP fracture risks, calculated using FRAX ${ }^{\circledR}$ score with $\mathrm{BMD}$ and without $\mathrm{BMD}$, are considered, major OP fracture with BMD 94.7\% ( $n=322)$ was low, 5.0\% $(n=17)$ was middle, and $0.3 \%(n=1)$ was in the high-risk group; for major OP fracture without BMD, 91.8\% ( $n=312)$ was low, $7.6 \%(n=26)$ was middle, and $0.6 \%(n=2)$ was in the high-risk group (Table 2). When participants' femur fracture risk with BMD and without BMD were assessed, $97.9 \%(n=333)$ had low risk for femur fracture with BMD, $1.8 \%(n=6)$ had middle, and $0.3 \%$ had $(n=1)$ high risk, and for femur fracture without BMD, 97.1\% $(n=330)$ 
Table 1. The sociodemographic characteristics of participants

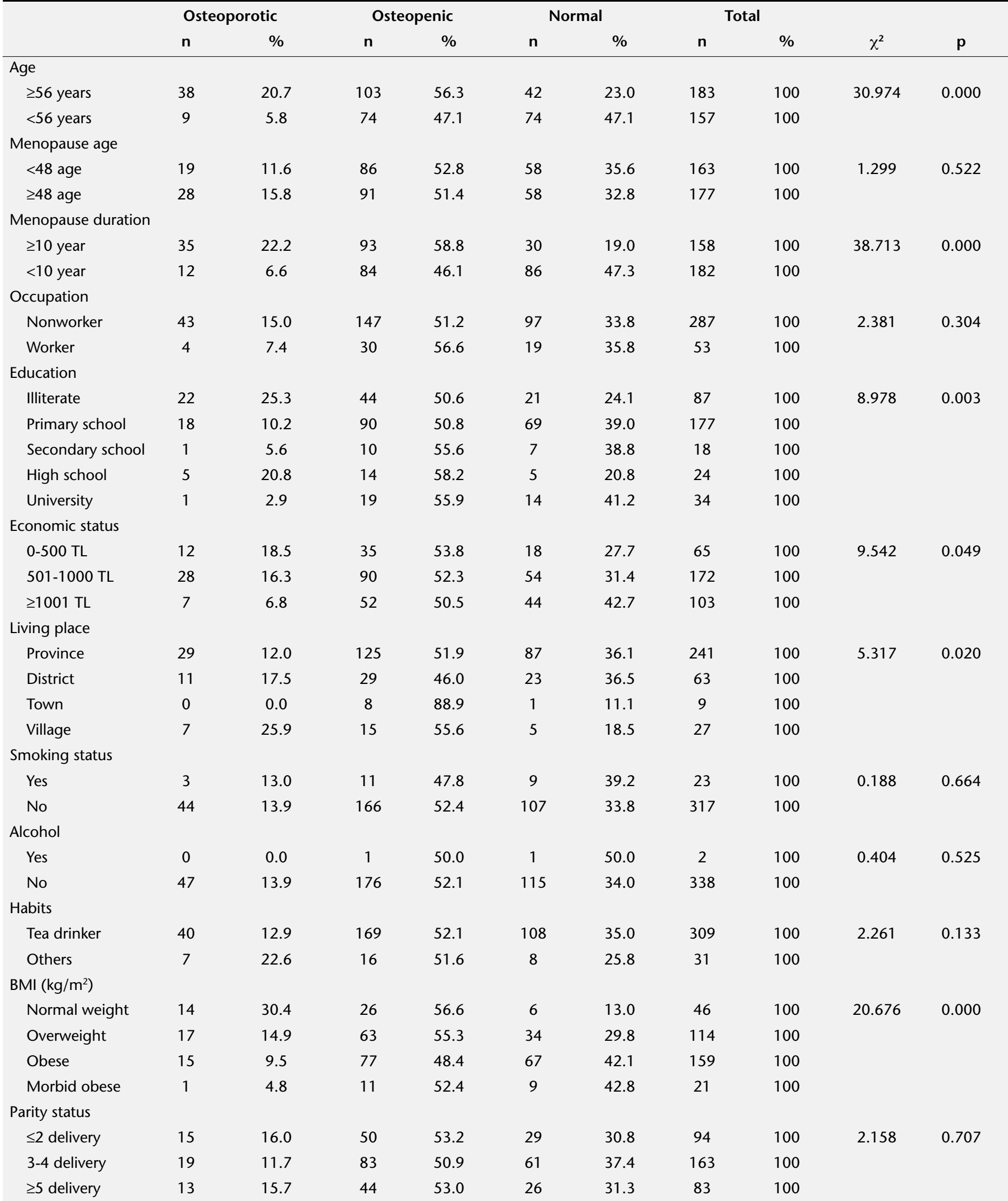


Table 2. The rate of major OP fracture risks calculated with BMD and without BMD

\begin{tabular}{|c|c|c|c|c|c|c|}
\hline & \multicolumn{2}{|c|}{$<10 \%$ low risk } & \multicolumn{2}{|c|}{$10 \%-20 \%$ middle risk } & \multicolumn{2}{|c|}{$\geq 20 \%$ high risk } \\
\hline & $\mathbf{n}$ & $\%$ & $\mathbf{n}$ & $\%$ & $\mathbf{n}$ & $\%$ \\
\hline Major OP fracture using BMD & 322 & 94.7 & 17 & 5.0 & 1 & 0.3 \\
\hline
\end{tabular}

OP: osteoporosis; BMD: bone mineral density

Table 3. The rate of femur fracture risks calculated with BMD and without BMD

\begin{tabular}{|c|c|c|c|c|c|c|}
\hline & \multicolumn{2}{|c|}{$<5 \%$ low risk } & \multicolumn{2}{|c|}{$5 \%-10 \%$ middle risk } & \multicolumn{2}{|c|}{$\geq 10 \%$ high risk } \\
\hline & $\mathrm{n}$ & $\%$ & $\mathrm{n}$ & $\%$ & $n$ & $\%$ \\
\hline Femur fracture with BMD & 333 & 97.9 & 6 & 1.8 & 1 & 0.3 \\
\hline
\end{tabular}

BMD: bone mineral density

Major OP fracture using BMD

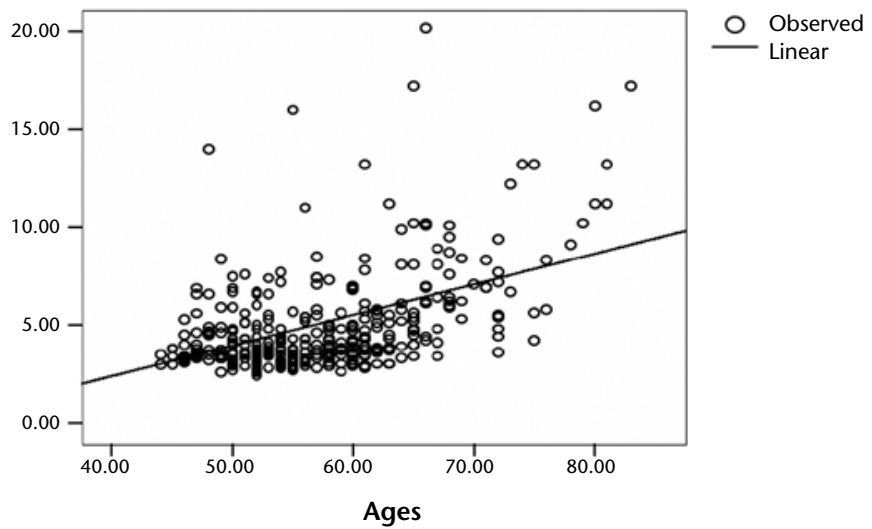

Figure 2. Linear regression analysis between major OP fracture risk with $\mathrm{BMD}$ and age

OP: osteoporosis; BMD: bone mineral density

was low, $2.3 \%(n=8)$ was middle, and $0.6 \%(n=2)$ was in the high-risk group (Table 3).

When the correlation between major osteoporosis risk with $B M D$, age, and menopause period was examined, it was found that while there was a positive mild-degree relation, there was a positive highly significant relation between major osteoporosis risk without $B M D$, age, and menopause period $(p<0.001)$. When linear regression analysis was done, it was found out that there was a positive statistically significant relation between major osteoporosis risk with $\mathrm{BMD}$ and without $\mathrm{BMD}$ and age $(\mathrm{p}<0.001)$; major OP fracture risk with $B M D$ was attributed to age at $22.9 \%\left(R^{2}=0.229\right)$, and the major OP fracture risk increase without BMD was $31.7 \%\left(R^{2}=0.317\right)$, attributed to age (Figure 2,3). When the correlation between major osteoporosis risk with BMD and without BMD and glucocorticoid use was examined, there was a negative mildly significant relation. There was positive mild relation between major osteoporosis risk with $\mathrm{BMD}$ and $\mathrm{CRFs}$, and there was a positive, highly significant relation between major osteoporosis without BMD $(p<0.001)$.
Major OP fracture without using BMD

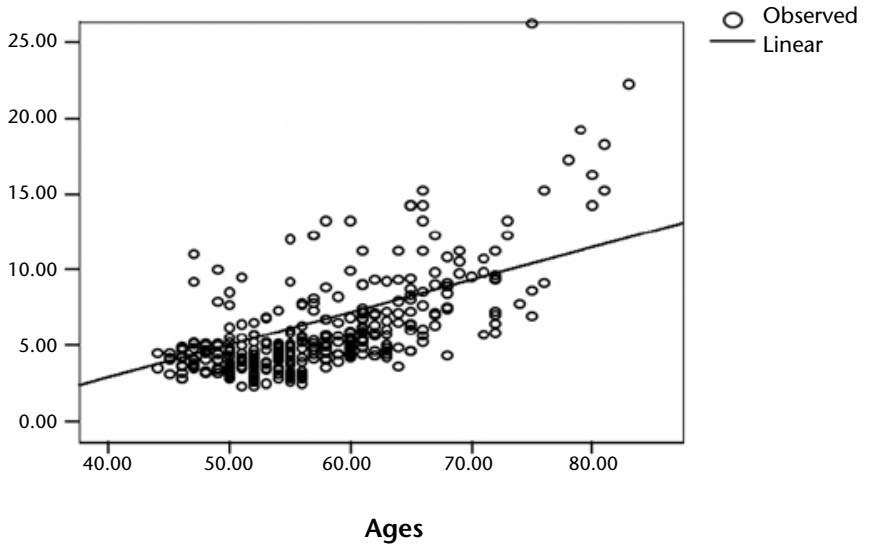

Figure 3. Linear regression analysis between major OP fracture risk without BMD and age

OP: osteoporosis; BMD: bone mineral density

When the correlation between femur fracture risk with BMD and without BMD and age was examined, it was seen that there was positive highly significant relation $(p<0.001)$. In the linear regression analysis, there was a positive statistically significant relation between age and femur fracture risk with BMD and without BMD $(p<0.001)$. While $27 \%\left(R^{2}=0.270\right)$ of increases in femur fracture risk with BMD was attributed to age, the increase in femur fracture risk with BMD was attributed to age at $44.3 \%$ $\left(R^{2}=0.443\right)$. The comparison of 10 -year possible major OP fracture risk with $\mathrm{BMD}$ and without $\mathrm{BMD}$ according to age is seen in Figure 4.

The comparison of 10-year possible femur fracture risk with BMD and without BMD according to age is seen in Figure 5.

When the correlation between femur fracture risk with BMD and BMI was examined, it was seen that there was a negative, mildly significant relation. However, it was seen that there was a negative mildly significant relation between femur fracture risk with $\mathrm{BMD}$ and $\mathrm{BMI}(\mathrm{p}<0.05)$. With the correlation between 


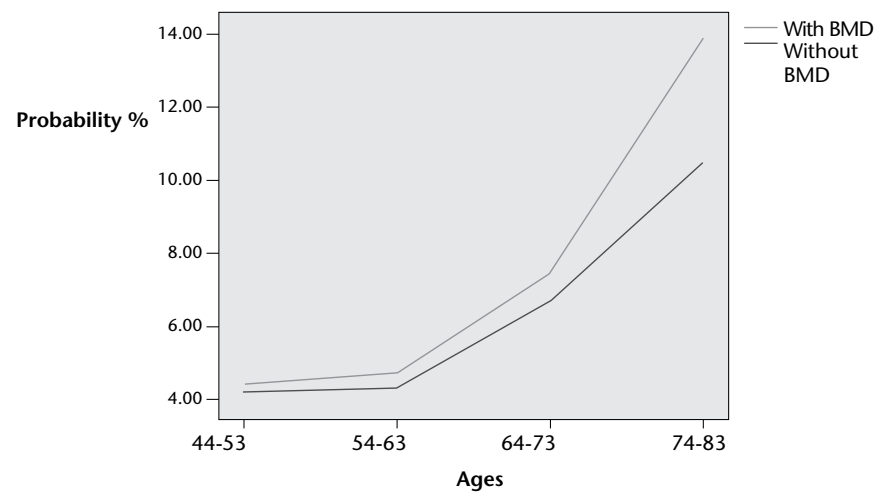

Figure 4. The comparison of 10-year possible major OP fracture risk with $\mathrm{BMD}$ and without $\mathrm{BMD}$ according to age BMD: bone mineral density

femur fracture risk with BMD and without BMD and previous fracture, it was seen that while there was a negative mildly significant relation, there was a positive weak relation between femur fracture with BMD and the number of CRFs, and there was a positive mildly significant correlation between femur fracture without BMD and the number of CRFs $(p<0.001)$. Whether $B M D$ was measured or not, the FRAX ${ }^{R}$ fracture risk assessment criterion is important in the determination of fracture risk.

\section{Discussion}

In this study, the osteoporosis frequency in postmenopausal women who participated in our study was determined to be $13.8 \%$. When osteoporosis risk factors were assessed, while OP frequency in those with 2 or fewer clinical risk factors was $12.8 \%$, OP frequency was $28.0 \%$ in those with 3 or 4 risk factors. Baim (15) reported that use of the combination of bone density and clinical risk factors had improved the prediction of low-trauma fractures.

As the BMI of the participants increased, OP frequency decreased, and there was a statistically significant relation between BMI and OP incidence frequency. In their study, IPPOT found a positive relation between BMD and BMI (9). Barrera et al. (16) reported that high $\mathrm{BMI}$ has protective effects on femur neck BMD. These results support the results of our study and that fat tissue has protective effects against OP.

In our study, OP was seen in $21.8 \%$ of those with previous fracture history. In a study by Erkin et al. (17), 11 out of 77 geriatric patients had a fracture history. Seven of the patients with fracture history were found to be osteoporotic, and 3 of them were osteopenic.

In our study, there were 8 women with rheumatoid arthritis (RA), 5 of whom were osteopenic. None of them was OP. In another study, decreased BMD was commonly seen in RA patients (18).

In a study by Franek et al. (19) on the calculation of fracture risk in Poland, the authors accepted $10.0 \%$ to $20.0 \%$ as threshold levels for major OP fracture risk and $5.0 \%$ to $10.0 \%$ as threshold levels for femur fracture risk. But, they could not explain how facture risk threshold levels were determined. Although it is not clear how to accept high fracture risk as an intervention threshold, it is considered that in general, this threshold varies along societies, depending on financial capability (20).

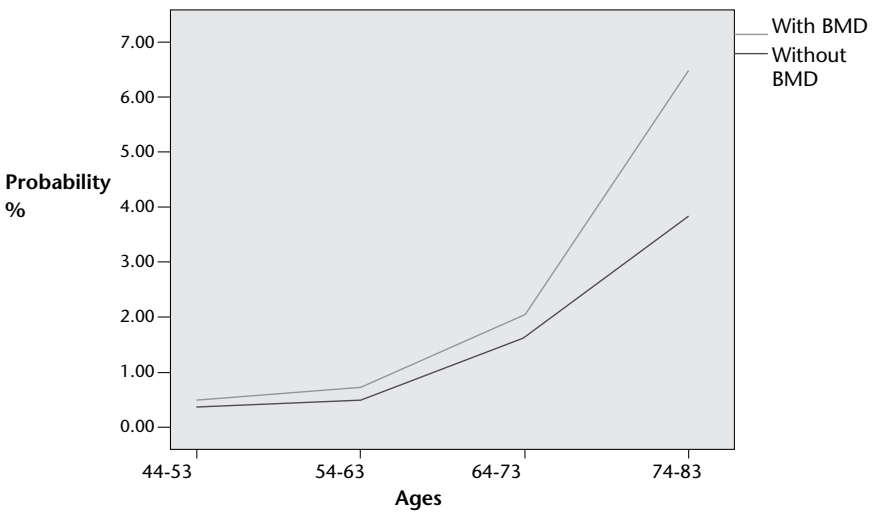

Figure 5. The comparison of 10-year possible femur fracture risk with $\mathrm{BMD}$ and without BMD according to age

In their study, Fujiwara et al. (21) determined that the intervention threshold for 10-year major osteoporotic fracture risk for 50 -year-olds is $5.0 \%$ and more than $20.0 \%$ for 80 -year-olds and that in determining fracture risk, femur neck BMD use will be better compared to lumbar BMD.

In a study by Li et al. (22), OP frequency was $37.2 \%, 10$ year estimated major osteoporotic fracture risk was $13.8 \%$ without considering BMD, femur fracture risk was 2.2\%, and major osteoporotic fracture risk for women over 70 was found to be $24.3 \%$. Kutlu et al. (23) found that for a major osteoporotic fracture, the probability ranged from $0.5 \%$ to $12.0 \%$ and from $0.1 \%$ to $7.1 \%$ with or without the measurement of BMD, respectively. These findings were similar to our results. In a multicenter retrospective study by Pedrazzoni et al. (24) in Italy, it was determined that the median value for 10 -year facture risk in postmenopausal women was $7.5 \%$, and for femur fracture risk, it was $1.7 \%$. In $25.0 \%$ of the participants, the 10 -year fracture risk for major osteoporosis was $\geq 12.1 \%$, and for femur fracture risk, it was determined to be $\geq 4.1 \%$.

Before discussing the results, the limitations of the present study must be considered.

Our data have been obtained from relatively small patient samples. This study was conducted in a medical faculty hospital, which limits our ability to generalize the results to a general Turkish population; however, this sample helped us to determine the osteoporosis (OP) risk factors in postmenopausal women and 10-year major osteoporosis and femur facture risks.

\section{Conclusion}

In conclusion, the 10-year probability of fracture with and without BMD was calculated by using $\mathrm{FRAX}^{\circledR}$. Following the assessment of fracture risk using FRAX ${ }^{\circledR}$ in the absence of BMD, the patient may be classified to be at low, intermediate, or high risk.

- Low risk-reassure, give lifestyle advice, and reassess in 5 years or less depending on the clinical context.

- Intermediate risk-measure BMD and recalculate the fracture risk to determine whether an individualıs risk lies above or below the intervention threshold.

- High risk-can be considered for treatment without the need for BMD, although BMD measurement may sometimes be appropriate, particularly in younger postmenopausal women. 
Using FRAX ${ }^{\circledR}$ risk assessment criterion, which is developed based on unique data from each country and clinical risk factors, patients with high fracture risk can be determined at early periods, and proper osteoporosis treatments would be cost-effective. In this study, it has been determined that, with BMD or without BMD, the FRAX ${ }^{\circledR}$ risk assessment scale, which is used to assess 10-year OP fracture risk, is a significant, cost-effective, and easy-to-apply assessment criterion.

This study was conducted in a medical faculty hospital, which limits our ability to generalize the results to a general Turkish population; however, this sample helped us to determine the osteoporosis (OP) risk factors in postmenopausal women and 10-year major osteoporosis and femur facture risks.

Ethics Committee Approval: Ethics committee approval was received for this study from the ethics committee of Necmettin Erbakan University Faculty of Medicine.

Informed Consent: Written informed consent was obtained from patients who participated in this study.

Peer-review: Externally peer-reviewed.

Author Contributions: Concept - A.D., R.K., S.Ç.; Design - R.K., A.D.; Supervision - S.Ç.; Funding - A.D., R.K.; Materials A.D., R.K.; Data Collection and/or Processing - A.D., R.K.; Analysis and/or Interpretation - R.K.; Literature Review - R.K.; Writer - A.D., R.K.; Critical Review - S.Ç., R.K.

Acknowledgements: This work was financially supported by Selcuk University, Scientific Projects Research Coordination (BAP). We wish to thank the participating women for their valuable collaboration and kindness.

Conflict of Interest: No conflict of interest was declared by the authors.

Financial Disclosure: The authors declared that this study has received no financial support.

Etik Komite Onayı: Bu çalışma için etik komite onayı Necmettin Erbakan Üniversitesi Tıp Fakültesi'nden alınmıştır.

Hasta Onamı: Yazılı hasta onamı bu çalışmaya katılan hastalardan alınmıştır.

\section{Hakem değerlendirmesi: Dış bağımsız.}

Yazar Katkıları: Fikir - A.D., R.K., S.Ç.; Tasarım - R.K., A.D.; Denetleme - S.Ç.; Kaynaklar - A.D., R.K.; Malzemeler - A.D., R.K.; Veri toplanması ve/veya işlemesi - A.D., R.K.; Analiz ve/veya yorum - R.K.; Literatür taraması - R.K.; Yazıyı yazan - A.D., R.K.; Eleştirel Inceleme - S.Ç., R.K.

Teşekkür: Bu çalışma Selçuk Üniversitesi Bilimsel Araştırma ve Projeler Koordinatörlüğü tarafından (10102014 sayılı BAP ile) finansal olarak desteklenmiştir. Çalışmaya katılan kadınlara da değerli işbirliği ve uyumları için teşekkür ederiz.

Çıkar Çatışması: Yazarlar çıkar çatışması bildirmemişlerdir.
Finansal Destek: Yazarlar bu çalışma için finansal destek almadıklarını beyan etmişlerdir.

\section{References}

1. Yazici S, Yazici M, Korkmaz U, Engin Erkan M, Erdem Baki A, Erden l, et al. Relationship between blood pressure levels and bone mineral density in postmenopausal Turkish women. Arch Med Sci 2011;7:264-70. [CrossRef]

2. FRAX WHO Fracture Risc Assessment Tool. http://www.shef.ac.uk/ FRAX/tool.jsp? location Value=] Accessed date: 10.09.2011.

3. Retornaz F, Seux V, Pauly V, Nouvellet S, Flecher X, Soubeyrand J, et al. A fracture - intervention program optimizes the management of osteoporosis. Geriatr Psychol Neuropsychiatr Vieil 2011;9:437-44.

4. Shahla A. Validity of bone mineral density and WHO fracture risk assessment thresholds in hip fractures. Arch Iran Med 2011;14:352-4.

5. Hadjidakis DJ, Kokkinakis EP, Sfakianakis ME, Raptis SA. Bone density patterns after normal and premature menopause. Maturitas 2003;44:279-86. [CrossRef]

6. Kanis JA, Johnell O, Oden A, Johansson H, Mc Closkey E. FRAXTM and the assessment of fracture probability in men and women from the UK. Osteoporosis Int 2008;19:385-97. [CrossRef]

7. Dequeker J, Ranstam J, Valsson J, Sigurgevisson B, Allander E. The Mediterranean Osteoporosis (MEDOS) Study questionnaire. Clin Rheumatol 1991;10:54-72. [CrossRef]

8. Tuzun S, Eskiyurt N, Akarirmak U, Saridoğan M, Senocak M, Johansson $\mathrm{H}$, et al. Incidence of hip fracture and prevalence of osteoporosis in Turkey: the FRACTURK Study. Osteoporosis Int 2012;23:949-55. [CrossRef]

9. Kara IH, Aydin S, Gemalmaz A, Aktürk Z, Yaman H, Bozdemir N, et al. Habitual tea drinking and bone mineral density in postmenopausal Turkish women: investigation of prevalence of postmenopausal osteoporosis in Turkey (IPPOT Study). Int J Vitam Nutr Res 2007;77:389-97. [CrossRef]

10. WHO, Assesment of osteoporotic fracture risk and its role in screening for postmenopausal osteoporosis. WHO Technical report series 843,Geneva,1994. Available at: http://www.uspreventiveservicestaskforce.org/3rduspstf/osteoporosis/osteosumm2.htm. Accessed: 10.03.2012.

11. Johansson H, Kanis JA, McCloskey EV, Odén A, Devogelaer JP, Kaufman JM, et al. A FRAX(R) model for the assessment of fracture probability in Belgium. Osteoporos Int 2011;22:453-61. [CrossRef]

12. Guthrie JR, Ebelling PR, Dennerstein L, Wark JD. Risk factors for osteoporosis: prevalence, change, and association with bone density. Medscape Womens Health 2000;5:25-9.

13. Blank RD; FRAX(®) Position Development Conference Members. Official Positions for FRAX® clinical regarding prior fractures from joint Official Positions Development Conference of the International Society for Clinical Densitometry and International Osteoporosis Foundation on FRAX®. J Clin Densitom 2011;14:205-11. [CrossRef]

14. Lorenc RS, Misiorowski W, Karczmarewicz E. Critical points in strategies for the diagnosis and treatment of osteoporosis. Endokrynol Pol 2009;60:124-33.

15. Baim S. Assessment of fracture risk. Rheum Dis Clin North Am 2011;37:453-70. [CrossRef]

16. Barrera G, Bunout D, Gattas V, de la Maza MP, Leiva L, Hirsch S. A high body mass index protects against femoral neck osteoporosis in healthy elderly subjects. Nutrition 2004;20:769-71. [CrossRef]

17. Erkin G, Akınbingöl M, Gülsen ED, Aybay C, Özel S. The features of the geriatric patients who have bone mineral dansitometric measurements in our osteoporosis unit. Turkish Journal of Geriatrics 2004;7:84-8. 
18. Macovei L, Ancuta C, Belibou C, Chirieac R. Bone mineral density in patients with rheumatoid arthritis. Rev Med Chir Soc Med Nat lasi 2011;115:723-30.

19. Franek E, Wichrowska H, Gozdowski D, Puzianowska-Kuznicka M. WHO fracture risk calculator (FRAXTM) in the assessment of obese patient with osteoporosis. Endokrynol Pol 2009;60:82-7.

20. Kanis JA, Burlet N, Cooper C, Delmas PD, Reginster JY, Borgstrom $\mathrm{F}$, et al. European guidance for the diagnosis and management of osteoporosis in postmenopausal women. Osteoporosis Int 2008; 19:399-428. [CrossRef]

21. Fujiwara S, Nakamura T, Orimo H, Hosoi T, Gorai I, Oden A, Johansson $\mathrm{H}$, et al. Development and application of a Japanese model of the WHO fracture risk assessment tool (FRAX). Osteoporos Int 2008; 19:429-35. [CrossRef]

22. Li YM, Liu SH. Estimation of the 10-year Probability of Osteoporotic Fracture in Postmenopausal Taiwanese Women With FRAX. Tzu Chi Med J 2010;22:29-35. [CrossRef]

23. Kutlu R, Civi S, Pamuk G. Frequency of osteoporosis and calculation of 10-years fracture probability by using FRAXTM Tool in postmenopausal women. Turk J Phys Med Rehab 2012;58:126-35.

24. Pedrazzoni M, Girasole G, Giusti A, Barone A, Pioli G, Passeri G, et al. Assessment of the 10-year risk of fracture in Italian postmenopausal women using FRAX®: a North Italian multicenter study. J Endocrinol Invest 2011;34:386-91. 